\title{
コミュニケーションロボットのための 対人距離に基づく集団状態推定手法の提案
}

\author{
塩見昌裕 $* 1$ 神田崇行*1 野 原 健 太*1*2 \\ 石黒 浩 $* 1 * 2$ 萩 田 紀 博*1
}

\section{Estimating Group States for Communication Robots}

\author{
Masahiro Shiomi*1, Takayuki Kanda*1, Kenta Nohara*1*2, \\ Hiroshi Ishiguro ${ }^{* 1 * 2}$ and Norihiro Hagita*1
}

\begin{abstract}
In human-robot interaction, communication robots must simultaneously consider interaction with a group of people in real environments such as stations and museums. To interact with the group simultaneously, it is important to estimate whether a group's state is suitable for the robot's intended task. This paper presents a method that estimates the states of the group of people for interaction between a communication robot and the group of people by focusing on the position relationships between clusters of people. In addition, we also focused on the position relationships between clusters of people and the robot. The proposed method extracts the feature vectors from position relationships between the group of people and the robot and then estimates the group states by using Support Vector Machine with extracted feature vectors. We investigate the performance of the proposed method through a field experiment whose results achieved an $81.4 \%$ successful estimation rate for a group state. We believe these results will allow us to develop interactive humanoid robots that can interact effectively with groups of people.
\end{abstract}

Key Words: Group State Estimation, Communication Robot, Proxemics, Field Trial

\section{1. 諸論}

近年，日常環境下で人々との相互作用を通じてサービスを提 供する，コミュニケーションロボットの研究が広く行われてい る [1]〜 [5]. 例えば，商業施設内で来客と顔見知りになるように 対話するロボット [1] [2] や, 介護施設で人々に癒しを与えるこ とを目的としたロボット $[3]$ などが存在する．このようなロボッ トらが人とより自然に相互作用を行うために，対話時に扔ける 身体性の有効性や [6] [7], 対話者の認識を行うためのセンサ処 理 [8] [9] 等の, 人・ロボット間相互作用に注目した研究が行わ れている.

日常環境下で活動するコミュニケーションロボットには, 上記 のような基本的な相互作用のための機能に加えて, 複数の人々 （集団）との相互作用を考慮した機能が必要となる。例えば，口 ボットが集団に対して情報提供するタスクを行う際には, 情報 提供の対象となる人々がロボットの発話を聞き取りやすいよう に, 人々がロボットに対して扇状に並ぶなどの, 整然とした状

原稿受付 2008 年 4 月 23 日

*1 株式会社国際電気通信基礎技術研究所知能ロボティクス研究所

$* 2$ 大阪大学大学院工学研究科

${ }^{* 1}$ ATR Intelligent Robotics and Communication Laboratories

${ }^{* 2}$ Graduate School of Engineering, Osaka University

口本論文は有用性で評価されました。
態であることが望ましい (Fig.1-(a))。これに対して，人々が ロボットに対して縦列に並んでいる状態や, ロボット周辺に人々 が集まっていない状態などの, 雑然とした状態は, 夕スクを行 う上で望ましくない状態である。例えば, Fig. 1-(b)に示す状 態では，ロボットの周囲に人々が扇状に並ぶことができるだけ の領域が存在しているにもかかわらず，情報提供の対象となる 人々の多くがロボットの側面や背面に存在している。この状態 は, Fig.1-(a)のような状態に比べて，一部の人々のみがロボッ トと対話して抢り，タスクを行う上で望ましくない状態である と考える。このような場合, ロボットは集団の状態を認識し, 何 らかの働きかけを通じて自らのタスクに適した状態を作り出す

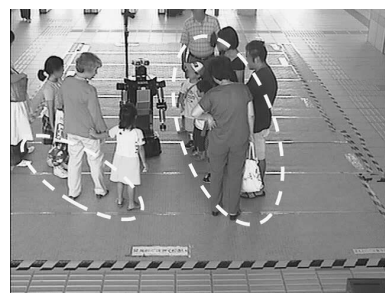

(a) People standing in front of robot

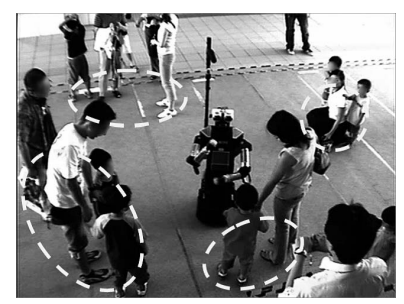

(b) Small scattered group around the robot
Fig. 1 Robot simultaneously interacting with many people 
必要がある。つまり，日常環境下でロボットが集団とより自然 に相互作用を行うためには, 集団の状態を推定する機能が必要 となる。

これまで，複数人の位置情報や集団の混雑度などに注目した 研究は, 過去に広く行われている. 人の位置推定に関する研究 は，現在においても広く行われており [10]〜 [12], 例えば近年で は駅構内などの実環境下で, 頑健かつ高速に複数人の位置追跡 を行う手法が提案されている [10]. 位置情報の変化がもたらす 意味に注目した研究には, 推定した位置の時系列情報から人々の 振る舞いを推定したり [13], 複数人の位置情報から混雑度を推 定したりするものがある [14]. しかし，より円滑な集団・ロボッ 卜間相互作用を実現するために必要となる，ロボットと対話し ている集団の状態を推定することを目的とした研究はなかった。

本研究では，集団状態を推定するために，Fig. 1 に示される ような，集団を構成するより小さな集団（クラスタ）に注目し た。これまでにも, 集団や群衆のクラス夕分析を行う研究は数 多く行われており, 複数の人々の社会的な交流に関する環境デ ザインや [15], 人間関係に基づく対人距離の解析 [16] [17], 環境 と混み合いに関する心理学的な解析 [18] などが行われている. 本研究では, ロボットと対話している集団の位置情報をクラス 夕分析の対象とし, 各クラスタの大きさや形状, 位置関係から 集団の状態推定を行う，例えば，ロボットが情報提供を行う際 の整然とした状態は, Fig. 1-(a)に示されるように, ロボットの 前方にクラスタが集中し, 各クラスタとロボットの距離関係は 似通ったものになると予想できる。一方で, 雑然とした状態に おいては，Fig. 1-(b)に示すように，ロボットから離れた位置に 複数のクラス夕が存在することや, クラスタの形状がロボット に対して縦列に変化することが予想できる，よって我々は，口 ボットと各クラスタの位置関係を利用することで, 集団状態を 推定できると考えた。

しかし，ロボットと各クラスタの位置関係を計算するために は，適切なクラス夕数を何らかの方法で決定しなければならな い.人々の数やロボットとの位置関係によって最適なクラスタ 数は変化するため, 状況に応じたクラス夕の分割が必要となる. そこで本研究では, 最適なクラス夕数を決定するために, クラ ス夕を構成する人々同士の距離，対人距離に注目した，過去の 研究から, 人同士の対人距離は, その人々の持つ人間関係や, 目 的によって変化することが報告されている [17]. 例えば，家族 や友人関係を持つ人々や，「ロボットと対話しよう」という共通 の目的を持つ人々同士の距離は小さくなり，その人々はクラス 夕を構成する。一方で，特にロボットへの興味を持っていない 人々や，共通の目的を持たない他人同士の距離は大きくなり, ク ラス夕を構成しない。そこで我々は, 何らかの関係を持つと予 想される人々同士を一つのクラスタとして扱うことで, 状況に 応じた最適なクラスタ数が決定できると考えた。つまり本研究 では，人々の対人距離に基づいて，集団を構成するクラス夕を 計算し，ロボットと各クラスタの位置関係に基づいて集団状態 の推定を行う。

\section{2. 集団の状態}

\section{1 推定対象とする集団状態}

本研究では，集団の状態がロボットのタスクにとって望まし い状態であるかどうかを推定することを，目的とする．しかし， ロボットのタスクが変化することで，集団とロボットの望まし い位置関係は変化する。例えば，ロボットのタスクが集団に対す る情報提供であった場合には，人々がロボットに対して扇状や， 横列に並んでいる状態が望ましいが，ロボットのタスクが集団 を連れて施設内を案内する場合には, 人々がロボットの後方に 縦列に並んでいる状態が望ましい. 過去の研究においても, 集 団の形状は夕スクに応じて変化することが報告されている [19]. 例えば，駅の改札口付近では縦列に，互いに会話をする状況で は円状に集団の形状が変化する。つまり, ロボットの夕スクに 応じて, 異なる望ましい集団の形状やクラスタの位置関係が存 在すると考える.

そこで本研究では，ロボットが情報提供タスクを同時に 5 人 以上の人々に対して行う状況を対象として, 集団の状態がタス クに適した状態であるか，適していない状態であるかの 2 状態 を推定する手法を提案する. 人々の数を 5 人以上とした理由は, ある程度の人々がロボットの周囲に存在していない状況では, 集 団形状の変化が小さく, 集団状態の推定が困難になると考えた めである，ここで，情報提供夕スクを対象とした理由は，この夕 スクが日常環境下で人々との相互作用を行うロボットにとって 非常に基本的なタスクであり，かつ集団状態推定がより有効な ためである.実際に，これまでに行われた日常環境下でのロボッ トを用いた実証実験において，多くのロボットに基本機能とし て情報提供タスクが実装された [1] [2] [20]. 実証実験においてロ ボットは，自身の目新しさを積極的に活用することで，多くの 人々の興味を惹きつけ，情報提供を行った。 そのなかで, Fig. 1 に示されるような, ロボットと集団が相互作用を行う場面は, 頻 繁に観察されている [20].このような状況下において，ロボッ トが集団状態を推定することができれば，より効率よく情報提 供を行うことができると考える。

本論文では，ロボットの情報提供タスクに適した状態を「整 然とした」状態，タスクに適していない状態を「雑然とした」 状態と記述する。 以下に, 本研究における各状態の定義を記述 する。

整然とした状態：ロボットの周囲 $4[\mathrm{~m}]$ 以内に存在している 5 人以上の人々が，ロボットの方向を注視しており，かつ人々が ロボットの正面方向に集まっている，すべての人々が情報提供 を受けるうえで適していると思われる場面 (Fig. 2 左部).

雑然とした状態：ロボットの周囲 $4[\mathrm{~m}]$ 以内に存在している 5 人以上の人々が, ロボットの方向を注視しており, かつ人々が ロボットの正面方向に集まっていない，すべての人々が情報提 供を受けるうえで適していないと思われる場面 (Fig. 2 右部).

本研究では，この 2 状態の分類を 2 人の評定者によって行っ た.ここで, 評定者間で意見の相違があった状態については扱 わない.つまり本研究では，2人の評定者らが互いに「整然と した」・雑然とした」と判断した明確な場面を, 精度よく推定 することを目的とする。 


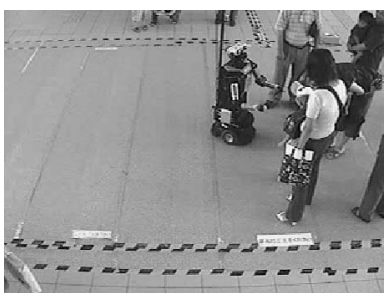

(a) People spread around robot

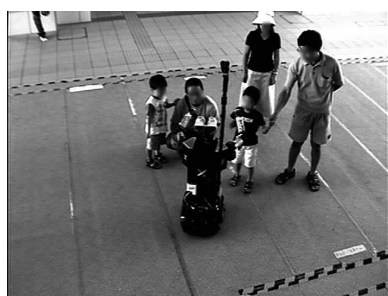

(b) People standing in front of robot

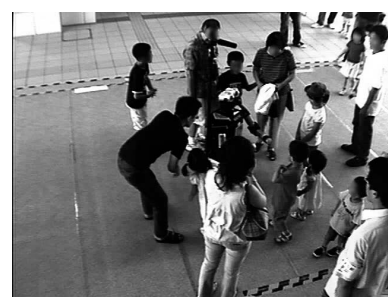

(c) People standing behind robot

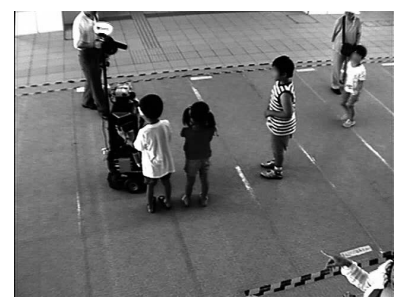

(d) People lined up to robot

Fig. 2 Example scenes: orderly and disorderly

Fig. 2-(a) (b) に，評定者らの判断が一致した整然とした状態 の例を示す.これらの例では, 複数の家族がロボットの正面方 向に集まっており，ロボットとの対話を通じて情報提供を聞い ている状態であった. 次に, Fig. 2-(c) (d) に評定者らの判断が 一致した雑然とした状態の例を示す。これらの例では, 複数の 家族がロボットの周辺に存在しているものの, 人々がロボット を取り囲んだり，一部の人々がロボットから離れて観察したり している状態であった。このような状態では，ロボットの正面 方向に存在している一部の人々のみが，ロボットと対話するこ とができた。

\section{2 位置情報に基づく集団状態推定}

本研究では, 環境に設置されたセンサから得られる, 人の位 置情報に基づいて集団状態の推定を行う。これは, 集団状態を 推定するために, ロボットから遠く離れた人々や, 背面に存在 する人々との位置関係が必要となるためである.

過去に行われた， ロボット単体のセンサを用いた人位置検出 に関する研究では, マイクロホンアレイ・カメラ・距離センサ等 を利用した物がある [4] [8] [9]. しかし, 本研究では集団との対 話を対象としており，特に Fig. 2-(c)に示すような，ロボット が人々に取り囲まれている状態では, ロボット単体のセンサを 用いてロボット周辺に存在するすべての人々の位置情報を精度 よく推定することは困難であると考える。また, 駅やショッピ ングモール等の実環境では, 通行人や環境から発せられる突発 的な雑音, 照明条件の動的な变化や通行人による遮蔽などの影 響が存在する。

そこで本研究では, 人々の位置情報を推定するために, 環境 に設置するタイプの床センサに注目した。床センサは日常環境 下での照明条件の変化や, 人・障害物による遮蔽の影響に頑健 で, 安定して人の位置を取得できるという利点を持つ. 床セン サを用いることで, Fig. 2 に示すような, 日常環境下でロボッ 卜が大勢の人々に囲まれる状況下でも, 人々の位置を頑健に取 得できる. 実際に, 過去に行われた研究でも, 人々の多いショッ ピングモール内で人々の位置情報を取得するために, 床センサ が用いられている $[2]$.

\section{3. システム構成}

本章では, 本研究で提案する集団状態推定システムの処理の 流れ（Fig. 3）について述べた後, 各項目の詳細について述べ る. 本研究で提案する手法の流れを, 以下に示す.

（1）ロボットは環境に設置されたセンサから, 人々の位置情報

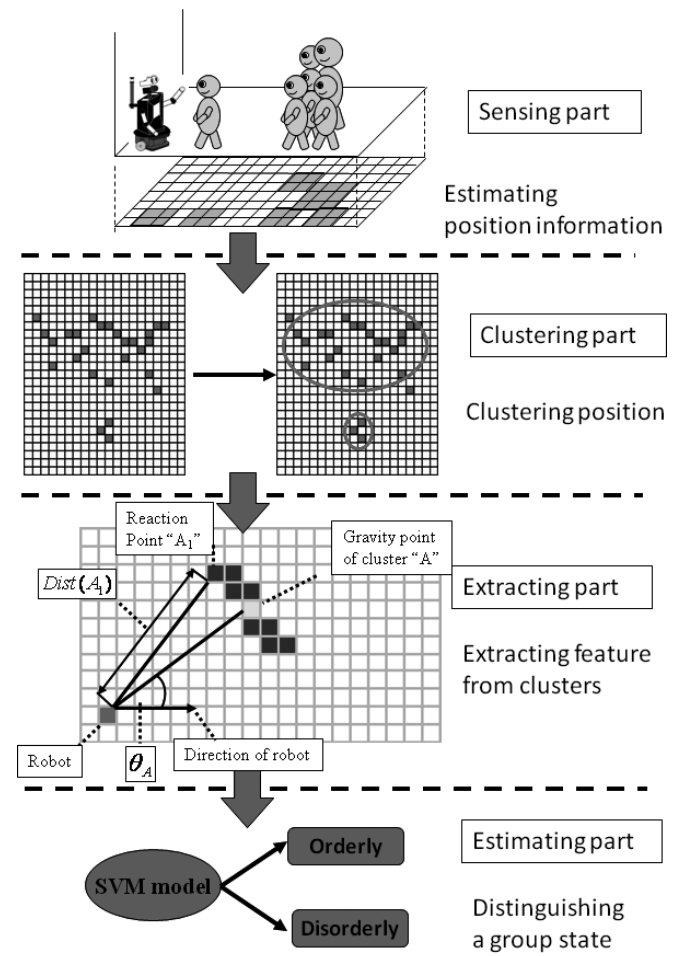

Fig. 3 Outline of developed system with proposed method

を取得する (センシング部，3.1 節参照)。

（2）人々の位置情報からクラスタを計算するために, 対人距離 の知見に基づいてクラスタリングを行う（クラスタリング 部, 3.2 節参照).

(3) 分割されたクラスタとロボットの位置関係をもとに, 集団 の状態を推定するための特徵量を抽出する（特徵量抽出部, 3.3 節参照).

（4）サポートベクターマシン（SVM） [21] を用いて，推定され た特徵量から集団状態の推定を行う。(集団状態推定部, 3.4 節参照).

3.1 センシング部

センシング部では, 集団の状態を推定するために, 環境センサ を用いて集団を構成する人々の位置情報を取得する. 本研究で用 いた床センサ（VSTONE 製，VS-SF55）の外観を Fig. 4-(a) に, 床センサの出力例を Fig. 4-(b) に示す. この床センサは, 加 重によって ON/OFF を出力するスイッチの集合から構成され ており，センサ上に存在する人の重みを検知できる。床センサの 


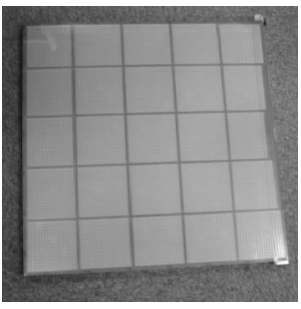

(a) An image of floor sensor

Fig. 4 Floor Sensors

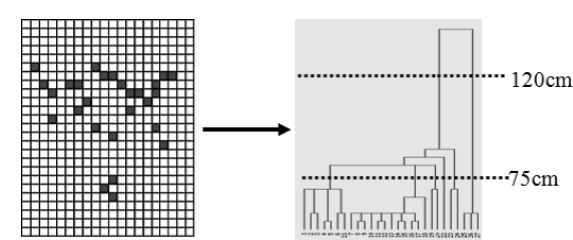

Fig. 5 Cluster tree diagram from floor sensors data

外形寸法は $500 \times 500 \times 15[\mathrm{~mm}]$ であり, 取得デー夕の検出解 像度は $100 \times 100[\mathrm{~mm}]$ である. 圧力感度は $200 \sim 250\left[\mathrm{~g} / \mathrm{cm}^{2}\right]$ であり, 感圧部分は約 $5[\mathrm{~mm}]$ 間隔で敷設されている. 床センサ のインターフェースには RS232C が用いられており，200[ms] 間隔でセンサ出力を取得できる。

\section{2 クラスタリング部}

クラスタリング部では, 床センサの出力值に対して対人距離 に基づくクラスタリングを行い, 集団を構成するクラスタの分 割を行う。本節では, 床センサ值のクラスタリング手法, およ びクラスタの分割手法について述べる.

\subsection{1 クラスタリング手法}

集団状態を推定するために, 本研究では床センサから取得さ れた人々の位置情報に対してクラスタリングを行い, 集団を構 成するクラス夕を計算する。 このとき, クラスタ数は集団を構 成する人々の数や対人距離によって変化するため, あらかじめ その数を決定することは困難である。 また，人々の位置関係に よってクラス夕の形状は複雑に変化する。 そのため, クラス夕 数が未知の状態で, 複雑な形状のクラスタを計算できるクラス タリング手法が必要となる。

クラスタリングの手法には, Nearest Neighbor 法 (以下, NN 法と記述する) や重心法, ウォード法等が存在するが, 提案手法 では NN 法を用いた，その理由として，NN 法は階層的なクラ ス夕構造を表現でき, クラスタリングを行う前にクラスタ数を 決定する必要がない点が挙げられる，また，集団内のクラス夕 は人々の位置関係によって複雑に変化すると考えられるが, NN 法は例えば棈円形や扇状, 鎖状等の複雑な形状をもつクラス夕 を表現することができる。これは，NN 法が各クラスタ間距離 が最小であるクラス夕同士を用いてクラスタリングするためで ある. 以上の理由から, 本研究では NN 法をクラスタリング手 法として利用した. Fig. 5 に, NN 法を用いて構築されたクラ スタ群と, クラス夕間の樹形図を示す. Fig. 5 の縦軸は, クラ ス夕間の距離の大きさを示す。

\section{2 .2 クラスタの分割}

Fig. 5 に示すように, NN 法によってクラスタリングされた クラスタは, クラスタ間距離を縦軸とした樹形図で表現できる。 本手法では, 集団状態を推定するために必要となる特徽量抽出 を行うために, クラス夕間距離によるクラスタの分割を行う。本 手法では, E.T. Hall の対人距離に関する知見に基づいて，ク ラスタ分割を行った. Hall は, 親しい人同士や初対面の人同士 で無意識に確保される対人距離を, 数段階の範囲に分類してい る [17].このなかで, 友人や家族などの親密な関係にある人々 や，立ち話や列をなしている人々の対人距離が「固体距離」とし て定義されて打り，その距離は扮打よそ $75[\mathrm{~cm}]$ から $120[\mathrm{~cm}]$ である. 本手法では, この知見に基づいて, クラス夕分割を行う 閾値を設定した。つまり本手法では，クラスタ間距離が $75[\mathrm{~cm}]$ 未満であれば分割を行わず， $120[\mathrm{~cm}]$ 以上であれば分割を行い， クラスタ数の候補を計算した。

ここで, Fig. 5 に示すように，クラス夕間距離が $75 \sim 120[\mathrm{~cm}]$ となるクラスタ数が複数存在する場合には, 集団状態を推定す るために最適なクラス夕数を決定する必要がある. クラス夕分 割を行う際の基準量には, 疑似 $\mathrm{F}$ 統計量や $\mathrm{CCC}$ 基準, 疑似 $t^{2}$ 統計量等が存在する. 本研究では, クラス夕数の決定を行う指 標として，疑似 $t^{2}$ 統計量の変化に注目した $[22]$.

これを用いた理由は, 疑似 $t^{2}$ 統計量がクラスタリングを行 う際に結合した二つのクラス夕間の分離度合いを示すためであ る. 本研究ではあらかじめ対人距離に基づいてクラス夕分割数 をある程度決定しているため, 局所的な分離度合いを計算する 疑似 $t^{2}$ 統計量が, 本研究での手法に最も妥当なクラス夕分割 数を計算することが可能になると考えた.

クラスタ $\mathrm{P}$ と $\mathrm{Q}$ が結合してクラスタ $\mathrm{R}$ となる際の擬似 $t^{2}$ 統計量は, 式 (1) で表される。ここで, W(c) はクラス夕 c の 重心とクラス夕 $\mathrm{c}$ に含まれる全要素との距離の総和, $\mathrm{N}(\mathrm{c})$ は クラスタ $\mathrm{c}$ 内の要素数である. 本手法では, 疑似 $t^{2}$ 統計量の 変化量が，正の方向にもっとも大きく変化する直前のクラス夕 数を, 分割するクラス夕数の候補とした. 以下に, 対人距離と 擬似 $t^{2}$ 統計量に基づく, クラス夕数の決定方法を示す.

$$
\begin{aligned}
& \text { psuedo } t^{2}=\frac{W(R)-W(P)-W(Q)}{W(P)+W(Q)} \\
& \times(N(P)+N(Q)-1)
\end{aligned}
$$

（1）クラス夕間距離が $75[\mathrm{~cm}]$ 以上となるクラスタ数を, 分割す るクラス夕数の候補とする。候補がない場合には，もっと もクラスタ間距離が大きくなるクラスタ数を分割数とする.

（2）（1）で選ばれた候補の中から，クラス夕間距離が $120[\mathrm{~cm}]$ 未満となるクラス夕数を, 分割するクラス夕数の候補とす る。候補がない場合には，もっともクラス夕間距離が小さ くなるクラスタ数を分割数とする.

(3) 計算された候補数の中で, 疑似 $t^{2}$ 統計量が正の方向に最 も大きく変化している直前のクラスタ数を，分割するクラ ス夕数とする.

\section{3 特徵量抽出部}

特徵量抽出部では, 集団状態の推定を行うために, センシン グ部で取得された人々の位置情報, およびクラスタリング部で 
計算された各クラスタの情報を用いて，以下に示す特徵量の抽 出を行う。

（1）床センサで反応した点の総数

(2) クラスタ分割後のクラスタ数

(3) クラスタの重心と, ロボットの正面方向との角度差

(4) ロボットとクラスタを構成する要素との距離平均

（5）上記距離平均の標準偏差

なお，すべての特徵量はSVMでの計算に用いるために，0.0〜 1.0 の範囲に正規化を行った. 床センサで反応した点の総数は, 床センサの最大反応可能点数の 3,200 で割った值となる. クラ ス夕数は, 最大クラス夕数の 10 で割った值となる. 角度差は 360 で割った值となり, 距離平均は床センサ領域の対角線距離 で割った值となる。

角度差, 距離平均, 標準偏差に関しては反応点数が多い上位 3 クラス夕に対してそれぞれ計算した。 よって, 特徴量の次元 数は $1+1+(3 \times 3)$ の計 11 となった. 床センサの総反応点数 とクラスタ数は, ロボットの周辺に人々や集団がどの程度存在 しているかを表している. 角度差, 距離平均, 標準偏差は, 各 クラスタがどのような形をしており，ロボットとどのような位 置関係にあるかを表している。提案手法ではこれらの特徵量を 用いて，集団状態の推定を行う。

Fig. 3 の Extracting part に, 人々がロボットに対して扇状 に並んだ場合のクラスタリング例を示す．式（2）は，ロボッ トと各クラスタを構成する各要素との距離平均の算出方法を示 す.ここで, $N$ はクラスタ $A$ を構成する要素数を示している. Dist $\left(A_{i}\right)$ は, ロボットとクラスタ “ $A$ ” の $i$ 番目の要素であ る “ $A_{i}$ ”との距離を示している. 式 (3) は, 式 $(2)$ で計算さ れた距離平均の, 標準偏差の算出方法を示している. Fig. 3 の Extracting part における $\theta$ は, クラスタの重心とロボットの 正面方向との角度差を示している.

$$
\begin{gathered}
\mu_{A}=\sum_{i=1}^{N} \operatorname{Dist}\left(A_{i}\right) / N \\
\sigma_{A}=\sqrt{\sum_{i=1}^{N}\left(\mu_{A}-\operatorname{Dist}\left(A_{i}\right)\right)^{2} / N}
\end{gathered}
$$

\section{4 集団状態推定部}

集団状態推定部では，SVM と特徵量抽出部で抽出された 11 個の特徵量を用いて, 集団の状態が整然とした状態であるか, 雑 然とした状態であるかの推定を行う.SVM はパターン認識の 分野に打いて 2 クラスを分類するために広く用いられている手 法であり, 少数の学習データで性能のよい判別機を作成可能で あるという特徴を持つ [21]. 本研究では, LIBSVM を用いて判 別機の作成を行った [23].

判別機を作成するためには，あらかじめ学習デー夕を用意し， 学習を行う必要がある. 本研究では, 集団状態推定を行う判別 機を作成するために, 後述する実験で取得したデー夕の一部を 学習データとして利用した。

\section{4. 性能検証実験}

本章では，提案手法の有効性を検証するための，性能検証実

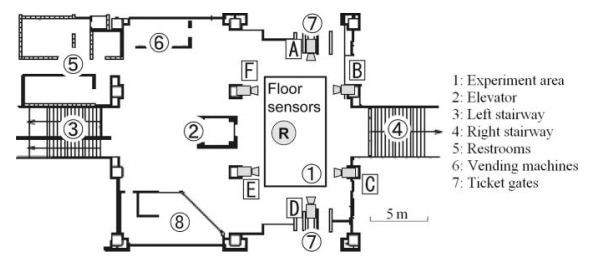

Fig. 6 Settings of pre-experimental environment

験の詳細について記述する. 本研究では, 提案手法の有効性を 検証するために, 日常環境下で実際にロボットが複数の人々と 相互作用を行う際のデータを取得した. 取得したデー夕は, 2 人 の評定者によって整然とした状態と雑然とした状態の 2 状態に 分類され，学習用デー夕掠よびテスト用データとして利用され た。本章では，これらの詳細について記述する。

\section{1 データ収集}

我々は，提案手法の有効性を検証するためのデー夕を取得す るために，駅構内に実験環境を構築し， 2 週間の実証実験を行っ た. 具体的には, 近鉄奈良登美ヶ丘駅構内に, 人との相互作用 機能を持つコミュニケーションロボット「Robovie」[24], 人々 の位置を取得するための床センサ，実験風景を記録するための カメラを設置し，ロボットが人々と相互作用する実験を行った。

本研究で実験を行った近鉄奈良登美ヶ丘駅は, 住宅地と都市 部を結ぶ路線の終端駅である. 1 時間に $4 \sim 7$ 本の電車が当該駅 から発射する。駅の主な利用者は通勤者や学生, そして週末に ロボットを見学に来た家族などである。利用者らは, 自由にロ ボットと相互作用を行うことができた。

Fig. 6 に, 実験環境と, ロボット㧍よびセンサの配置図を示す。 配置したロボットには, 駅周辺施設への道案内や, 駅周辺施設に 関する情報提供を行うタスクを与えた。床センサは, $4 \times 8[\mathrm{~m}]$ の領域内に 128 枚設置された。 人々が床センサ上に存在した場 合，ロボットは自律的にその人々に近づき，情報提供を行った。 ロボットと人々が相互作用する様子は, 天井に設置された 6 台 のカメラによって記録された.

実験では 1,000 人以上の人々がロボットとの対話を行い, そ のなかから 5 人以上の人々が 5 秒以上ロボットの付近で立ち止 まり，ロボットを注視していた場面を 152 個取得した。各場面 の記録映像を 2 人の評定者に提示し，各場面を整然とした状態. 雑然とした状態に分類した. その結果, 各場面は 72 個の雑然 とした状態と， 36 個の整然とした状態に分類された（1 週目の データからは 36 個の雑然とした場面と 18 個の整然とした場面 が, 2 週目のデータからも 36 個の雑然とした場面と 18 個の整 然とした場面が分類された).

整然とした場面と，雑然とした場面の各床センサデー夕の例 を，Fig. 7 に示す。これらのデー夕は，それぞれ Fig. 1-(a) (b) に対応する物である。

ここで, 評定者間の判断の妥当性を検証するため, 我々は評 定者間の主観的な評価の一致度合いを検証した。評価の一致度 合いが低い場合には, 集団状態の分類に用いた定義が不適切で あり，判別対象として扱うことが妥当ではない，と考えるため である. 判断の一致度合いを検証するために, 本研究では $\kappa$ 統 計量を計算した $[25] . \kappa$ 統計量は, 複数の評定者がラベル付け 


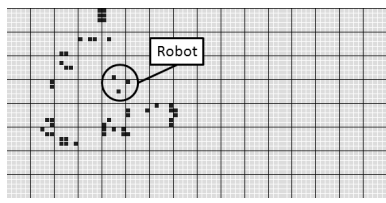

(a) People standing in front of robot (Fig. 1-(a))

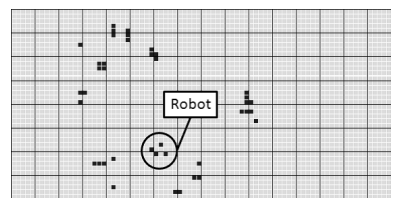

(b) Small scattered group around the robot (Fig. 1(b))
Fig. 7 Floor sensors data in orderly/disorderly scenes

を行った際の, 評価の正確さや妥当さを示す值である． $\kappa$ 統計 量は， $\kappa>0.6$ であればかなりの一致度合いを， $\kappa>0.4$ であ れば中程度の一致度合いを示している。本研究では， $\kappa=0.49$ であったことから， 2 人の評定者による主観的な評価を集団状 態推定に利用することは，妥当であると考えた。

\section{2 判別機作成}

集団状態推定を行うために必要となる判別機を作成するため に, 本研究では分類された各状態の半分を学習デー夕作成に用 いた。つまり，実験の 1 週目で取得された， 36 個の雑然とした 状態と 18 個の整然とした状態から, 学習デー夕の作成を行った. 具体的には, 雑然とした状態の場面からは 2 秒分の床センサ出 力を, 整然とした状態の場面からは 4 秒分の床センサ出力を学 習デー夕作成に利用した。ささらに，データの総数を増やすため に, 実際に取得した床センサ出力からダミーデータを生成した。 ダミーデータの生成には, 床センサの出力值を X 方向に反転さ せたものを用いた．床センサのセンシング周期は $200[\mathrm{~ms}]$ であ るため, 整然とした状態・雑然とした状態のそれぞれにおいて 720 データが学習用に作成された。

提案手法の有效性を検証するために，2 種類の評価基準を用い た. 一つは, 判別機の性能評価に一般的に用いられる, K-fold cross validation 法である. 本研究では, 実験の 1 週目で取得 されたデータセットを 10 個に分割し，10-fold cross validation 法を用いて性能評価を行った。もう一つは, 実験の 2 週目で取 得されたデー夕を用いた性能検証である。これは, 実験の 1 週 目で取得されたデータセットを用いて作成した判別機を実際に 利用した状況を仮定し，未知のデータが与えられた際に十分な 汎用性を持っているかを検証することを目的としている。テス トデー夕は, 各状態に打ける残りの半分 (2 週目で取得された 36 個の雑然とした状態と 18 個の整然とした状態）を用いて作 成された。学習データと同様にダミーデータの作成を行い, 各 状態に対して 720 デー夕を作成した。

な打本研究では，提案手法の有効性を他の手法と比較するた めに, 以下に示す手法で抽出された特徵量を用いて, 異なる判 別機を作成した．まず，提案手法で注目した対人距離に基づく クラスタリングの有効性を検証するために, 疑似 $t^{2}$ 統計量の みを用いたクラスタリングとの性能比較を行った。また, SVM による判別機を作成するときに広く用いられる，センサ出力の Rawデー夕を用いた場合との性能比較を行った。 なお，判別機 の学習に用いるデータには，すべて同じものを使用した。

\section{Raw データ (3,200 次元)}

床センサの出力そのものを，特徵量として扱った．環境に設
Table 1 Average accuracy of estimating group states

\begin{tabular}{|c|c|c|}
\hline & 10-fold cross validation & Test data \\
\hline Raw data & $80.21 \%$ & $50 \%$ \\
\hline Psuedo $t^{2}$ & $72.01 \%$ & $67.43 \%$ \\
\hline Proposed method & $76.39 \%$ & $81.04 \%$ \\
\hline
\end{tabular}

置された床センサは 128 枚であり，1 枚につき 25 個の出力が 行われるため, 合計 3,200 次元となった.

\section{疑似 $t^{2}$ 統計量のみを用いたクラスタリング（11 次元）}

取得された床センサ出力に対して, 対人距離に基づくクラス 夕数の分割を行わず, 疑似 $t^{2}$ 統計量が正の方向の最も大きく変 化している直前のクラスタ数を分割するクラスタ数として, 特 徵量抽出を行った。

\section{3 性能検証}

Table 1 に，提案手法扔よび比較手法に扔ける，10-fold cross validation 法を用いた場合と，テストデー夕を用いた場合の判 別率を示す.

10-fold cross validation 法を用いた場合には, Raw data を用 いた場合の判別率が最も高い值となり, 提案手法よりも約 $4 \%$ 性 能が高かった。しかし，テストデー夕を用いた場合には，提案 手法を用いた場合が比較手法の判別率に比べて 15 30\%ほど高 い值となった。これは, 未知のデータが判別機に与えられた場 合に, 提案手法が最も精度よく集団状態を推定できたことを示 している.

これらの結果は, 対人距離の知見に基づいて行ったクラス夕 リングと, 特徵量抽出が集団状態推定に有効であることを示し ていると考える，特に，集団を対人距離に基づいてクラスタリ ングすることで, 集団を構成するクラスタとロボットとの位置 関係（距離・標準偏差・角度）を特徵量として抽出することが 可能になったことが，性能向上に寄与したと考える.

\section{5. 考察}

\section{1 人・ロボット間相互作用への応用可能性}

提案手法を用いることで，約 80\%の精度で整然とした状態・ 雑然とした状態を正しく推定できた. Raw データを用いた場合 や，疑似 $t^{2}$ 統計量のみを用いたクラスタリングなどの場合よ りも，約 15 30\%以上高い精度で集団状態を判別できた。これ らの結果から, 提案手法を用いることで, コミュニケーション ロボットがより集団と円滑に相互作用可能になると考える。例 えば，集団の状態が杂然としている場合には，ロボットは集団 に対して自身に注目するように呼び掛けるなどの振る舞いを行 うことで, 集団の状態をロボットに適した状態に制御すること が可能となる。

また，提案手法は以下に示す三つの理由から，広い応用性を 備えていると考える。一つ目の理由は, 異なる実環境への応用 可能性である. 本研究では, 性能検証のために, 日常環境下で 実際にロボットが人々と相互作用した状況下でのデー夕を用い た．実験室などの統制された環境ではなく, 一般の人々が自由 にロボットと相互作用した状況下に扔いて, 集団状態推定を約 $80 \%$ の精度で実現できたことは, 本提案手法の応用範囲の広さ を示していると考える. 
二つ目の理由は，異なるセンサを利用したシステムへの応用 可能性である，本研究では，騒音や照度変化，移動する人々に よる遮蔽などの外乱の多い環境下を対象としたため，人々の位 置を取得するために床センサを用いた。 しかし, 本提案手法で は基本的に人々の位置が取得可能であれば，異なるセンサを用 いたシステムに対しても適用可能であると考える。例えば，環 境内に設置されたレーザレンジファインダなどで推定された人 の位置や，天井カメラなどによって推定された顔の位置などに 対してクラスタリングを行うことで，本研究と同様に集団状態 の推定が可能になると考える.

三つ目の理由は, 異なる集団状態推定への応用可能性である. 本研究では, 情報提供タスクを行う際の整然とした状態・雑然と した状態の推定を行った。ここで, 推定する状態は, 複数の評 定者によって分類されたものを対象としている. そのため, 評 定者らが分類に用いた定義を変更することで，異なる状態の推 定も容易に実現できる。例えば，人々がロボットに対して縦列 に並んでいる場面を，「整然とした状態」として分類すること で，異なる状態を推定することができる，ロボットのタスクに 応じて適切な集団の形状は変化するが，提案手法を用いること で，各夕スクに応じた適切な集団状態を推定することが可能に なると考える.

\section{2 性能向上に関する考察}

本研究で行った実証実験を通じて，我々は 2 種類の集団状態 推定性能の低下要因を発見した. 本章では. 各要因の詳細と, そ の対策について議論を行う。

\section{センシング部における人位置取得の失敗}

集団状態推定が失敗する要因の一つに，人位置取得の失敗が 挙げられる，床センサが人を検出できなかった主な原因は，人の 体重が軽いことと，センサの境界部に人が存在していたことが 挙げられる。床センサが人位置を取得できなかった状況は，小 さな子供が床センサ上に存在したときに, 時折観測された. 床 センサは遮蔽や照明条件の変化に強いものの，このような条件 下では人を検出することができなかった。

この問題を解決するためには，より感度の高い床センサを用 いる方法や, 圧力に応じてアナログ值で出力を行う床センサを 用いる方法があると考える。また，異なる種類の環境センサを 併用することでも, 問題の解決が可能であると考える. 例えば, 複数のレーザレンジファインダを用いて体の向き情報を推定す るシステムや $[26]$, 天井カメラと距離センサを連動させた高精 度の顔領域追跡システムが近年実現されている [27].このよう なシステムを用いて，顔の座標情報や向き情報を特徵量に用い ることで，より正確な集団状態推定が可能になると考える.

\section{異なる特徵量を用いた集団状態推定}

本研究では，ある時刻における床センサ出力のみを用いて， 集団状態推定を行った。しかし，ある時刻のみに注目した場合， 上述したセンシング部の人位置取得失敗などの要因により，集 団状態推定の性能が低下することが予想される。そのため, 例 えば床センサを用いて人々の位置追跡を行ったり [11]，各クラ スタから計算される特徵量の時系列変化を観測したりすること で，センシング部の外乱に頑健な集団状態推定を実現できると 考える.
また，位置追跡を行うことによって，個々の人々の移動速度や 滞在時間, 過去の行動の変化（ロボットとすでに相互作用して いるかどうか) 等の特徵量が抽出可能である．移動速度や移動 方向といった情報を用いることで，人々が対話相手であるのか， 単なる通行人であるのかを区別することが可能になる．さらに， 顔の向きなどの情報をカメラを用いて取得することで，人々が ロボットに注視しているかどうかを推定することができる.こ れらの特徴量を用いてクラスタリングを行うことで, 集団状態 推定の性能向上が可能であると考える。

\section{6. 結論}

本論文では，日常環境下で集団に対して情報提供を行うコミュ ニケーションロボットのための, 集団状態推定手法を提案した. 提案手法は，集団の状態が整然とした状態か，雑然とした状態 のどちらであるかを推定する. 集団状態推定のために, 提案手 法では床センサを用いて人々の位置情報を取得した。次に, 取 得した位置情報に対して，NN 法を用いてクラスタリングを行 い，対人距離に基づく知見と疑似 $t^{2}$ 統計量を用いてクラス夕 の分割を行った。そして, 分割したクラスタから集団状態を推 定するための特徴量を抽出し, SVM を用いて作成した判別機 によって集団状態の推定を行った.

提案手法の有効性を検証するために, 本研究では駅構内でロ ボットと一般の人々が相互作用を行う実証実験を行い，検証用 データの取得を行った。実験の結果，提案手法は $81.04 \%$ の性能 で集団状態を推定することができた。対人距離に基づかない特 徵抽出を行った場合よりも，提案手法は 15～30\%以上高い性能 を実現した。我々は，提案手法を用いることで，コミュニケー ションロボットがより円滑に集団と相互作用を実現できると考 える. 今後, 本研究の成果を利用して, 集団状態に応じて自身 の振る舞いを変化させる，より高度なコミュニケーション能力 をもったロボットの開発を行う.

謝 辞 実験環境を提供していただき，様々なご支援をして いただいた近畿日本鉄道株式会社様，近鉄奈良登美ヶ丘駅の皆 様に厚く感謝申し上げます。本研究は科研費（20700191）の助 成を受けたものである。

\section{参 考 文 献}

[1] 村川賀彦, 神田真司, 十時伸 十時郁代：“サービスロボット enon の 開発 $(2)$ : 商業施設での試験運用”, 第 24 回日本ロボット学会学術 講演会予稿集 CD-ROM，2006.

[2] 宮下善太, 神田崇行, 塩見昌裕, 石黒浩, 萩田紀博：“顧客と顔見知り になるショッピングモール案内ロボット”, 日本ロボット学会誌, vol. 26, no.7, pp.821-832, 2008.

[ 3 ] T. Shibata: "An overview of human interactive robots for psychological enrichment," The proceedings of IEEE, 2004.

[ 4 ] H. Asoh, S. Hayamizu, I. Hara, Y. Motomura, S. Akaho and T. Matsui: "Socially Embedded Learning of the Office-Conversant Mobile Robot Jijo-2," Int. Joint Conf. on Artificial Intelligence, pp.880-885, 1997.

[5] F. Tanaka, A. Cicourel and J.R. Movellan: "Socialization between Toddlers and Robots at an Early Childhood Education Center," Proceedings of the National Academy of Sciences of the USA, vol.104, no.46, pp.17954-17958, 2007.

[6] 小嶋秀樹, 高田明: “社会的相互行為への発達的アプローチー 社会の なかで発達するロボットの可能性”, 人工知能学会誌, vol.16, no.6, 
pp.812-818, 2001.

[ 7 ] 松坂要佐, 東条剛史, 小林哲則：“グループ会話に参与する対話口 ボットの構築”, 電子情報通信学会論文誌 D-II, vol.J84-D-II, no.6, pp.898-908, 2001.

[8] 中臺一博, 日台健一, 溝口博, 奥乃博, 北野宏明: “ヒューマノイドを対 象にした視聴覚統合による実時間人物追跡—アクティブオーディショ ンと顔認識の統合—”, ロボット学会誌, vol.21, no.5, pp.517-525, 2003.

[ 9 ] 加賀美聡, 佐々木洋子： “移動ロボットからの複数音源の定位と分離の ためのマイクアレイ評価”, 計測と制御, vol.46, no.6, pp.453-459, 2007.

[10] 中村克行, 趙卉菁, 柴崎亮介, 坂本圭司, 大鋸朋生, 鈴川尚毅：“複数 のレーザレンジスキャナを用いた歩行者トラッキングとその信頼性評 価”，電子情報通信学会論文誌，J88-D-II-7，pp.1143-1152，2005.

[11] 村北卓也, 石黑浩：“複数仮説化周期歩行モデルに基づく床センサネッ トワークを用いた実時間複数人物追跡”, 電子情報通信学会論文誌, vol.J90-D, no.6, pp.1555-1567.

[12] J. Cui, H. Zha, H. Zhao and R. Shibasaki: "Laser-based Interacting People Tracking Using Multi-level Observations," Proc. 2006 IEEE/RSJ Int. Conf. on Intelligent Robots and Systems

[13] 神田崇行, 塩見昌裕, 野村竜也, 石黒浩, 萩田紀博：“RFID 夕グを用 いた科学館来館者の移動軌跡の分析”, 情報処理学会論文誌, vol.49, no.5, pp.1727-1742, 2008.

[14] K.F. MacDorman et al.: "A memory-based distributed vision system that employs a form of attention to recognize group activity at a subway station," IROS2004, pp.571-576, 2004.

[15] R. Sommer: "Sociofugal space," American Journal of Sociology, vol.72, no.6, pp.654-660, 1967.

[16] R. Sommer: "Personal space," The Behavioral Basis of Design, Prentice Hall, Englewood Cliffs, New Jersey. 1969.

[17] エドワード・ $\mathrm{T}$ ・ホール 著, 日高敏隆, 佐藤信行 訳: かくれた次元. (IROS), 2006.

みすず書房, 1970 .

[18] 伊藤教子：“混み合いに関する環境心理学的考察：公共的な空間を対 象とした検討”, 博士学位論文, 早稲田大学人間科学学術院, 2003 .

[19] A. Kendon: 'Spatial Organization in Social Encounters: the F-formation System,' A. Kendon, ed., Conducting Interaction: Patterns of Behavior in Focused Encounters. Cambridge University Press, 1990.

[20] M. Shiomi, et al.: "A Semi-autonomous Communication Robot-A Field Trial at a Train Station-," ACM/IEEE 3rd Annual Conference on Human-Robot Interaction, pp.303-310, 2008.

[21] V. Vapnik: The Nature of Statistical Learning Theory. Springer, 1995.

[22] G. Milligan and M. Cooper: "Methodology Review: Clustering Methods," Applied Psychological Measurement, vol.11, pp.329-354, 1987.

[23] C.C. Chang and C.J. Lin: LIBSVM: Introduction and Benchmarks, http://www.csie.ntu.edu.tw/cjlin/libsvm.

[24] 神田崇行, 石黒浩, 小野哲雄, 今井倫太, 前田武志, 中津良平: “研究用 プラットホームとしての日常活動型ロボット “Robovie” の開発”, 電 子情報通信学会論文誌 D-I, vol.J85-D-I, no.4, pp.380-389, 2002.

[25] J. Carletta: "Assessing agreement on classification tasks: the kappa statistic," Computational Linguistics, vol.22, no.2, pp.249-254, 1996.

[26] S. Nishio et al.: "Robotic Platforms Structuring Information on People and Environment," IEEE/RSJ International Conference on Intelligent Robots and Systems, 2008.

[27] Y. Matsumoto, et al.: "Scalable multi-people head tracking for robotic services combining multiple sensors," The 5th International Conference on Ubiquitous Robots and Ambient Intelligence, 2008.

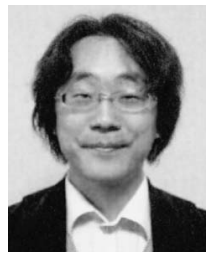

神田崇行 (Takayuki Kanda)

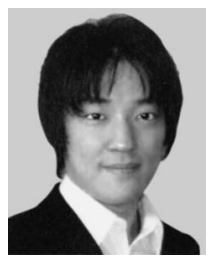

塩見昌裕（Masahiro Shiomi）

2003 年和歌山大学システム工学部卒業. 2004 年大 阪大学大学院工学研究科知能 ·機能創成工学専攻博 士前期課程修了. 2007 年同専攻博士後期課程修了. 博士 (工学). 現在, ATR 知能ロボティクス研究所 研究員としてコミュニケーションロボットの研究に 従事.ネットワークロボット，コミュニケーション ロボット，集団とロボットの相互作用に興味を持つ。

（日本ロボット学会正会員）

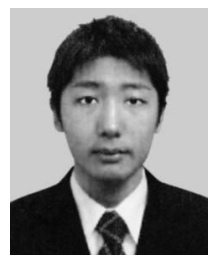

\section{野原健太（Kenta Nohara）}

2006 年大阪大学工学部卒業. 同年より同大学大学 院工学研究科, 知能 - 機能創成工学専攻博士前期課 程修了. 2005 年より 2008 年まで ATR 知能ロボ ティクス研究所学外実習生. 2008 年 4 月よりダイ キン工業株式会社に勤務。

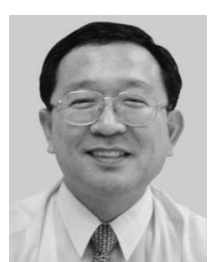

萩田紀博（Norihiro Hagita）

1978 年慶應義塾大学大学院工学研究科電気工学専 攻修士課程修了. 同年日本電信電話公社 (現:NTT) 武蔵野電気通信研究所に入所. 文字認識や画像認識 などの研究に従事. NTT 基礎研究所などを経て, 現在 ATR 知能ロボティクス研究所所長. 工学博士. IEEE，電子情報通信学会，情報処理学会，人工知 能学会などの会員.

(日本ロボット学会正会員)
1998 年京都大学工学部情報工学科卒業. 2000 年同 大学大学院情報学研究科社会情報学専攻修士課程修 了. 2003 年同専攻博士課程修了. 博士 (情報学). 現在, ATR 知能ロボティクス研究所上級研究員. ヒューマンロボットインタラクション，特にロボッ 卜の自律対話機構や社会的能力, 人間型ロボットの 身体を利用した対話に興味を持つ。

(日本ロボット学会正会員)

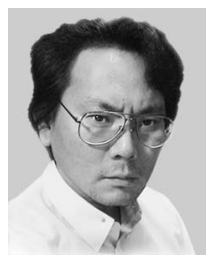

石黒 浩 (Hiroshi Ishiguro)

1991 年大阪大学大学院基礎工学研究科物理系専攻 博士課程修了. 工学博士. 同年山梨大学工学部情報 工学科助手, 1992 年大阪大学基礎工学部システム 工学科助手. 1994 年京都大学大学院情報学研究科 社会情報学専攻助教授. 2001 年和歌山大学システ ム工学部情報通信システム学科教授. 現在, 大阪大 学大学院工学研究科知能・機能創成工学専攻教授, ATR 知能ロボティ クス研究所第二研究室客員室長. 視覚移動ロボット, 能動視覚, パノ ラマ視覚, 分散視覚に興味を持つ. 人工知能学会, 電子情報通信学会, IEEE, AAAI などの会員.

(日本ロボット学会正会員) 